\title{
Kherzet Youcef Mine Flooding of 2nd June 1990 Revisited (Northeastern of Algeria) Origine and Hydrogeological Consequences
}

CHEDDAD Souhila ( $\sim$ cheddadsouha@gmail.com )

Houari Boumadiene University of Science and Technology

Haouchine Abdelhamid

Houari Boumadiene University of Science and Technology

\section{Research Article}

Keywords: Mining, mining risks, vertical electric sounding, mining dewatering, Kherzet Youcef deposit

Posted Date: November 4th, 2021

DOI: https://doi.org/10.21203/rs.3.rs-1028995/v2

License: (c) (i) This work is licensed under a Creative Commons Attribution 4.0 International License.

Read Full License 


\section{Abstract}

This work is part of the hydro geological study of the Kherzet Youcef deposit. The polymetallic deposit of Kherzet Youcef is known since the beginning of the 20th century. It is known by the exploitation of Lead and Zinc ore. It is located $50 \mathrm{Km}$ southeast of Setif (North-eastern Algeria) and $5.5 \mathrm{Km}$ west of Ain Azel. Mineralization can be described by some ore bodies (about 25). The thickness variate from a few centimeters up to $3 \mathrm{~m}$. These bodies are located on the layers of dolomite and dolomitized marl and along the Kherzet Youcef fault. The geological reserves of Zinc and Lead ore are of the order of 1.6 million tons. This ore has a $\mathrm{Pb}$ content of $3.6 \%$ and $\mathrm{Zn}$ content of $18.4 \%$. The projected annual exploitation was 100 thousand tons per year.

Hydro geological studies carried out successively (1973-1977) and (1981-1983) revealed the existence of an aquifer system located west of the Kherzet Youssef fault. It is characterized by the presence of Karts and by strong cracking due to local brittle tectonics. These two characteristics define the filtration and storage capacity of very abundant groundwater. This groundwater represented a major handicap for mining in view of the large amounts of water that required the installation of major pumping and drainage devices. The Kherzet Youssef mine has experienced frequent flooding in the past at a time when technology could not pump efficiently. It caused the mine to close several times.

In June 1990, the mine experienced a flood of great magnitude that has never been observed and despite the large installed means of pumping, this 'water costled to the total drowning of the mine, the death of 19 workers and the stoppage of the exploitation of this deposit since. Pitting attempts were carried out with a pumping capacity of $1100 \mathrm{~m} 3 / \mathrm{h}$, then $1800 \mathrm{~m} 3 / \mathrm{h}$ but without success. The interpretation of the drawdown data and field observations made it possible to conclude that this accident was only the result of the general destabilization of the massif.

Our complementary work by geophysical prospecting made it possible to represent the configuration of the underground layers and demonstrate the hydrodynamic communication between the two East and West compartments of the deposit.

\section{Introduction}

Mining is a special activity because of its importance in the economy. It consists in the exploitation of the natural resources of a territory and thus affects all countries, whether developed or not. This activity is intrinsically linked to the notion of risk, everyone had in mind the miner working underground in appalling conditions.

Among these risks, flooding of a mine is very common. Several mines in the world have experienced this risk. A study of mining periodicals was conducted from 1980 to 1996 (Peter 2011). This study shows that there are about two (02) water strokes per year, causing large production losses or other fatalities. The study did not analyze data from mines in China and the former USSR. The water stroke locations 
examined are: Africa, 9, North America, 6, Asia-Pacific, 5, Australasia, 5, Europe, 5, India, 2 and South America, 1.

There are divers reasons for water strokes. But according to the literature (Singh, 1986), three categories are distinguished:

- Controlled water flows into blasted mine openings below either a pressurized aquifer or a surface water body. The blow of water is followed by the collapse of the main roof and the flow of the coming water increases sharply in a short time to then decrease exponentially and return to the normal level.

- Spontaneous water flows when the mine is in the vicinity of a karst aquifer.

- Accidental water strokes in the vicinity of large bodies of water.

This is the case of the accident at the Kherzet Youcef deposit that took place on June 02, 1990, and caused the death of 19 miners and the closure of the mine since that date. This deposit experienced several water flows, but which were not of the magnitude of the flow of the accident. (ENOF, 2002)

Our ambition is to explain the causes of the accident, through the various works carried out on the deposit.

\section{Material And Methods}

\section{General information about the deposit area:}

Geographically, the deposit is located within the limits of the Hodna mountain range on the northeastern flank of the Jebel Hadjar Labiod chain, culminating at $1371 \mathrm{~m}$. East of the deposit, there is a vast intermountainous depression, with gentle slopes towards Ain Azel (Fig. 1). The climate of the region is continental. The latter is characterized by a hot, dry summer and a fairly cool, rainy winter.

The average annual temperature is of the order of 18 to $24^{\circ} \mathrm{C}$, ranging from $37^{\circ} \mathrm{C}$ and above, in summer to 3 to $4{ }^{\circ} \mathrm{C}$ in winter. The annual atmospheric precipitation is irregular and varies from 245 to $400 \mathrm{~mm}$. Due to the dislocation of the relief, the development of cracked and karstified rocks, as well as the absence of a plant layer, atmospheric precipitation infiltrates considerably. Water evaporation reaches 250-340 mm/year, or 75-85\%.

The river system is represented by a series of seasonal streams. Thus, through the deposit pass the wadis Ennza and Hamma, which have only a weak flow at times of torrential rains.

\section{Geological and structural framework:}


The Kherzet Youcef mine is located on the boundary between the Setifian high plains to the north and the Hodna Mountains to the South. The mining area is located at the eastern end of the Jebel Hadjar Labiod anticline (Fig. 2). (Bertraneu, 1955, Khaldi, 1987 and Boutaleb 2001)

This geological structure is extremely tectonized, faulted and presents itself in the form of a fold spilled to the South.

The northern flank of this structure shows a Jurassic-Cretaceous stratigraphic series about $1500 \mathrm{~m}$ thick.

The Cretaceous is the most important, because it is directly related to the exploited levels of the mine. It consists of the base at the top of three main units:

(1) Neocomian: Sandstone-marl and Pelitic,

(2) Barremian: A dolomite, calcareous argillites and sandstone,

(3) Aptian: Marl at the base and carbonate at the top.

The structural environment, of the mine, is complicated by a large North-South normal fault. Which limit the Jurassic and the Cretaceous formations to the West, Neogene and Quaternary deposits to the East.

According to the surveys carried out in the Ain Azel zone, the Neogene and the Quaternary appear to exceed $300 \mathrm{~m}$ in thickness.

The fault, as described by the mine's geologists, is in the form of a "gouge zone" or normal fault breaching zone.

This indicates that this fault must have played an important role during the Cretaceous and Tertiary. But it does not appear to have been very active during the Plio-Quaternary.

\section{Gitology:}

It is in the Barremian that the lead-zinc ore of Kherzet Youcef is located. The mineralization is interstratified in the form of "runs", very flattened layers located in the vicinity of the fault (Fig.3).

The number of mineralized layers and their strength increase near the fault. It form two distinct clusters:

(1) Upper beam, said "St. Stone " composed of five (5) main layers,

(2) Lower beam, said "St. Jean" composed of seven (7) main layers.

Mineralization follows $1200 \mathrm{~m}$ in length and over 60 to $80 \mathrm{~m}$ in width. The power of the layers varies from $10 \mathrm{~cm}$ to $7.5 \mathrm{~m}$. 
Ore structures are massive, brechic and sometimes concreted or banded. Paragenesis is simple: blende, galena, pyrite, marcasite, barite, calcite or banded.

A zonality of distribution of the ore with respect to the fault is clearly observed: indeed, the amount of metal square increases regularly when approaching the fault.

There is also a frequent occurrence of bitumen in the mineralized parts, filling joints and geodes, accompanying the pyrite (geological report on the Kherzet Youcef deposit, 1990).

\section{Data collection:}

Our approach in this work is based on the exploitation and interpretation of data from ancient geological and hydrogeological studies carried out on the deposit.

The available data are the results of pumping tests carried out as part of the hydrogeological study on the Kherzet Youcef deposit between 1976 and 1979. We also have the results of monitoring the pitting of the mine after the accident of June 02, 1990.

These data are supplemented by a field visit and geophysical prospecting by electrical sampling (Fig. 4).

The electrical equipment used in this study is composed of a high sensitivity Syscal type resistivimeter. It is equipped with a chain of battery cases and a set of coils carrying electrical wires, each one having a length of $500 \mathrm{~m}$ to adopt the $6000 \mathrm{~m}$ of emission. The data processing was carried out on the Ip2win software.

\section{Results And Discussions}

\section{General features of the hydrogeology of the Kherzet Youcef deposit:}

Hydrogeological studies carried out successively by SONAREM (1973-77) and EREM (1981-83), have revealed the existence of two (02) aquifer systems separated by the Kherzet Youcef fault:

(1) The Barremian carbonate system (CBS and CBi) west of the fault where the mineral deposit is located,

(2) The Neogene-Paleogene Quaternary system east of the fault, in the Ain Azel Depression. (NLT).

The first system is characterized by the presence of centimetric karsts $(3-5 \mathrm{~cm})$ and by strong cracking (cracks, diaclases and faults with low East-West rejection) due to local brittle tectonics. These two characteristics define the filtration and storage capacity of groundwater, which is very abundant judging by the pumping rates recorded at different levels of exploitation of the deposit (approximately $300 \mathrm{l} / \mathrm{s}$ ).

The pumping tests (SONAREM study 1973-77) and the observation of hydrogeological borehole on either side of the fault, showed that the two aquifer systems could be considered as having no connection. 
(Sonarem, 1979).

This finding was confirmed by Bellouche (1997). This author performed a statistical analysis (PCA) of the drawdowns caused by the pitting pumping of the mine to study its hydrodynamic functioning. He concluded that "the use of this method allowed us to support the hypothesis on the sealing of the Kherzet Youcef fault".

Finally, all of these aquifers are fed by rainfall and by underground flows from the Jebel Boutaleb and Hadjer Labiod reservoirs, located south and southwest of the deposit.

After the accident on June 02,1990 , mine engineers discovered that the second system actually consists of two aquifers.

(1) A shallow quaternary aquifer of low productivity (a few l/s) where the free water table is located in sand, pebble and gravel formations, interspersed with clays.

(2) A Neo-Paleogene aquifer with a charged water table (recommended operating flow: 10l/s) located in limestones, sands and conglomerates, attributed to the Miocene in the North and the Eocene in the South. (NCK)

These two aquifers are isolated from each other by an impermeable layer of argillite and marl (Fig.5).

A longitudinal geo-electrical section was drawn (Fig. 6). It extends from the Barremian calcareous dolomitic outcrops in the West (Not far from Kherzet Youcef), to the Miocene mound of Draâ Ben Aibouch in the East.

The cup finds the same collapsed structure, with a very resistant base ( $>500 \mathrm{ohm} . \mathrm{m}$ ) probably calcareous dolomitic in nature, corrugated and notched in several places by sub-vertical accidents.

The sedimentary cover, very heterogeneous, has a thickness that varies from $75 \mathrm{~m}$ at the location of the shoals (IIIK), to $600 \mathrm{~m}$ at the right of the tectonic pits (IIId).

Apart from the upper level, $170 \mathrm{~m}$ thick at most in the third, everywhere else the filling deposits contain a fairly large portion of clay.

Note also the position of the Kherzet Youcef normal fault as well as that of the gallery (overlap) made by the Sonarem at the $775 \mathrm{~m}$ which clearly confirms the hydraulic interconnection linking the Barremian compartment East and West, on either side of the fault.

\section{Estimation of water inflows by operating level:}

From the hydrogeological point of view the Kherzet Youcef deposit is complicated among the typical deposits. The highly developed network of tectonic accidents and the presence of karstified rocks give 
rise to rather complicated conditions for the circulation of groundwater. The filtration capacities of the rocks are extremely irregular both horizontally and vertically.

The main quantity of water flows into the mine shaft and into the mine works flow through certain open cracks in the tectonic zones, most often enlarged by the process of kartstification to considerable dimensions.

Therefore, we had to apply a conventional averaging of the calculations for the entire surface and depth of the deposit.

For the calculation of possible water flows in the mining works, the formula 'the large well' proposed by Troyanski was adapted using the Dupuit formula. According to this method, mining works will have the same area as a well of the same size.

$$
Q=1,366 \frac{K(2 H-s) s}{\log \left(R+r_{0}\right) \log r_{0}}, \text { where: }
$$

- $\mathrm{H}$ : thickness of the aquifer, $(\mathrm{m})$

- $s$ : lowering of the water level in the 'large well', taken equal from the static level to the operating depth, (m)

- R: radius of influence, $(\mathrm{m})$

- $r_{0}$ : radius of the 'large well', $(m)$

- K: permeability coefficient, $(\mathrm{m} / 24 \mathrm{~h})$

The mean permeability coefficient is calculated according to the Dupuit formula, using the results of the pumping tests (tracking the drawdown) at piezometers $(\mathrm{H} 1, \mathrm{H} 2, \mathrm{H} 4, \mathrm{H} 5, \mathrm{H} 6, \mathrm{H} 7$ and $\mathrm{H} 8$ ) around the mine (Fig.7) and the pumping test from the mining well Pit III.

The radius of the large well, it computes according to the following formula: $r_{0}=\frac{\sqrt{F}}{\pi}$, where:

$\mathrm{F}$, represents the area of the deposit, taken equal to $60000 \mathrm{~m}^{2}$, (length of the mineralized field is of the order of $1000 \mathrm{~m}$ and the average width is about $60 \mathrm{~m}$ ).

After the numerical application of Dupuit's formula, the results obtained are recorded in the following Table 1:

Table 01: Estimated water inflows by operating level 


\begin{tabular}{|c|c|c|}
\hline Depth (m) & $\begin{array}{c}\text { Operating level } \\
(\mathbf{m})\end{array}$ & $\begin{array}{c}\text { Flow rate } \\
\left(\mathbf{m}^{\mathbf{3}} \mathbf{h}\right)\end{array}$ \\
\hline 160 & 835 & 420 \\
\hline 280 & 715 & 596 \\
\hline 340 & 655 & 700 \\
\hline 400 & 595 & 778 \\
\hline 460 & 553 & 828 \\
\hline 520 & 475 & 851 \\
\hline
\end{tabular}

Fig. 8 shows the correlation between the flow rate of the water flows and the depth. We note that there is a strong positive correlation between the depth and the flow of the water flows.

The exhaust flows actually realized are higher than these calculated flows (ENOF, 2002). The actual discharge rates for operating levels 775 and 835 are shown in Table 2 below:

Table 2: Exhaust flow rate by operating level

\begin{tabular}{|c|c|c|c|}
\hline $\begin{array}{c}\text { Operating level } \\
(\mathrm{m})\end{array}$ & $\begin{array}{c}\text { Discharge rate } \\
\left(\mathrm{m}^{\mathbf{3}} / \mathbf{h}\right)\end{array}$ & Expected flow rate $\left.\mathbf{( m}^{\mathbf{3}} / \mathbf{h}\right)$ & $\begin{array}{c}\text { Margin of error } \\
(\%)\end{array}$ \\
\hline 835 & 531 & 420 & 26 \\
\hline 775 & 740 & 596 & 24 \\
\hline 692 & $823(1000$ before accident) & 700 & 18 \\
\hline
\end{tabular}

We notice that the margin of error is not large enough (an average of 23\%). The expected flow is less than the flow actually extracted from the mine. Due to the fact that we did not take into consideration, during the calculations, the discharge rate that is carried out during the tests (according to the documents of the mine).

\section{The disaster of 02/June/1990:}

The disaster of 02/June/1990 caused the death of 19 workers. The rupture, of this day, is located at level 775 on the side of the Kherzet Youcef fault, and caused the emptying of the captive sheet formed by the karst limestones. The piezometry of this sheet is not known before the accident. The emptying of the captive web is translated by a rise of $200 \mathrm{~m}$ and a filling of $225000 \mathrm{~m}^{3}$ of vacuum created by the mining works.

Cracks appeared in the ground a few months before the accident on June 02, 1990. These cracks developed several days before the accident and evolved into gaping cracks.

In the opinion of the engineers working on site, the cracks were minimal and limited around shaft l: they did not begin to evolve until August 1989. 
These cracks were attributed to surface effects due to collapses of old galleries. Work was then undertaken to map and record these surface cracks (Fig. 9).

\section{Interpretation of the causes of the accident}

The activation of the pumping system in the well $\mathrm{N}^{\circ} 3$, intended to ensure the progress of mining work, changes the hydrodynamic situation in a sudden way. The large drawdowns and partial drying of the CBs causing essential hydraulic disintegration of the hydrogeological units. This hydraulic decay occurs at the "macro" level (significant difference between the piezometric levels in the different units), as well as at the "micro" level (because of the well-expressed stratification of the CB and the embarrassed bonds among the different permeable ones).

Over time, we arrive at a highly disturbed piezometry, with large differences in hydrostatic pressures and hydraulic gradients in the different parts of the massif, that is to say, we arrive at a new distribution of tensions in the massif. By adding the presence of numerous mining works (galleries, shafts, descendents, etc..), it is not difficult to assume by the appearance of several cracks and deformation of the terrain.

The catastrophic accident is only a result of this general destabilization of the massif. The movements, even if quite small, threaten to produce new underground cracks, especially at more vulnerable points. Such a point turned out the overlap of the gallery at level 775 , located in the immediate vicinity of the Kherzet Youcef fault, respectively of the karst captive sheet (Fig.10).

The large load (more than $120 \mathrm{~m}$ above level 775) in the NCK and the karst character of the water table, resulted in a huge influx of water (several thousand $\mathrm{m} 3 / \mathrm{h}$ at the beginning). In a few hours the mine is completely drowned. It is also to sign the extraordinary rains fallen (and the flood passed in the wadi crossing the site) during the 3 - 4 days preceding the accident. The penetration of the waters into numerous cracks (open and quite deep) contributed to the further weakening of the massif (mainly clay layers) and to the internal movements that occurred.

Pumping over the following months allowed the lowering of the level in well III and currently it is supported at coast $770-775$. The flow drawn mainly comes from the source at level 775 (the flow drawn from the lower levels 692 cannot be specified, but it does not exceed 200 to $250 \mathrm{~m}^{3} / \mathrm{h}$ ).

At present, there is a progressive drying of the NCK carried out by the source at the level 775. At the start of pumping, the piezometric level of the NCK is lowered by a few hundred m (based on Pz03 data) and is now below the top of the water table (approximately at hill 800).

The drying of the water table will continue, which means a subsequent decrease in the flow of the source.

The data of the flows pumped during the months of September and October 1990 interpreted, in order to find a valid value of the drying coefficient $\alpha$ of the source. 
We obtained: $\alpha=0.0043 \mathrm{l} /$ day. Based on this value, we predicted the evolution of the flow rate (Q) over the following 15 months. At the end of 1991, a decrease in the drawn flow can be expected to about 800 $\mathrm{m}^{3} /$ h (Fig. 11).

However, it is possible that the decrease in the flow rate will be slowed down if the piezometric level of the NCK later reaches a strongly karstified zone.

The significant lowering of the piezometric level of the NCK could lead to some deformation of the terrain east of the fault. (About very recent cracks have already been noticed in this area).

\section{Conclusion}

During underground work or mining, groundwater is often a cause of obstruction, for a wide variety of reasons, which must be eliminated.

In carbonate terrains, water circulation is often favored by the presence of karstified fractures. As a result of the oxidation of sulphide deposits, groundwater becomes aggressive and has a destructive action both on metallic materials (pumps, pipes, ...) and on the host (dissolution of rocks).

In this type of deposit, the galleries are often invaded by water that can sometimes exceed $10 \%$ to $20 \%$ of the useful ore extracted. (Bellouche, 1996)

This is the case of the accident at the Kherzet Youcef deposit that took place on June 02, 1990, and caused the death of 19 miners and the closure of the mine since that date. This deposit experienced several water flows, but which were not of the magnitude of the flow of the accident. This accident was only the result of the general destabilization of the massif.

Our complementary work by geophysical prospecting made it possible to represent the configuration of the underground layers and demonstrate the hydrodynamic communication between the two East and West compartments of the deposit.

\section{References}

- BERTRANEU J. (1955) - Contribution à l'étude géologique des monts du Hodna (Massif du Boutaleb). Pub. Ser. Car. Géolo. De l'Algérie du N., série, Bulletin 4, p 1-182.

- BELLOUCHE M.A. (1997) - Apport de l'analyse en composante principales (A.C.P.) en hydrodynamique - exemple d'application sur la mine de Kherzet Youcef (Algérie nord orientale). PANGEA n 27/28. Pages 5-12.

- BELLOUCHE M.A. (1996) - L'eau dans les mines \& les travaux souterrains, cas de la mine de Kherzet Youcef (Ain Azel, Sétif). Mémoire de Magister, Université de Constantine. 169p.

- BOUTALEB A. (2001) - Les minéralisations à Pb-Zn du domaine Sétifien - Hodna : gitologie, pétrographie des dolomies, microthermométrie et implications métallogéniques. Thèse de Doctorat 
s'science, USTHB, Alger. $404 \mathrm{p}$

- DARLING Pr. (2011)- Society for mining, metallurgy and exploration editor: SME MINING ENGINEERING HANDBOOK.

- ENOF : Entreprise Nationale des Produits Miniers Non Ferreux, (2002)- Situation hydrogéologique du gisement de Kherzet Youcef. 10p.

- ENOF. (2013) - Etude hydrogéologique en vue du dénoyage de la mine de Kherzet Youcef. 50p.

- KHALDI A. (1987) - Le gisement de Kherzet Youcef : Une minéralisation Pb-Zn-Fe-Ba stratiforme dans le membre médian marno-carbonaté du Barrémien de la région d'Ain Azel (Hodna, Algérie). Thèse $3^{\text {ème }}$ cycle, Inst. Nat. Plolytec. De Loraine. 439p.

- JINKAI L. et WANGFANG Z. (1988) - Karst groundwater inrush and its prevention and control in coal mines in China. IAH, $21^{\text {st }}$ congress, Karst hydrogeology and karst environment protection. P $1075-$ 1082.

- QIREN L. (1988) - The basic hydrogeological characteristics of karst - water infilled mineral deposits and the hazard prevention, control and utilization of karst water in China. IAH, $21^{\text {st }}$ congress, Karst hydrogeology and karst environment protection. P 1089 - 1096.

- SINGH R. N. (1986). Mine inundations, International Journal of Mine Water, 5.

- SONAREM : Société Nationale de Recherche et d'Exploitation Minière (1979) - Travaux hydrogéologiques exécutés en 1973 - 1979 sur le gisement polymétallique de Kherzet Youcef. 87 p.

- Union économique BULGARGEOMIN (1990) - Le complexe d'exhaure au niveau 678 de la mine de Kherzet Youcef. 22p.

\section{Figures}




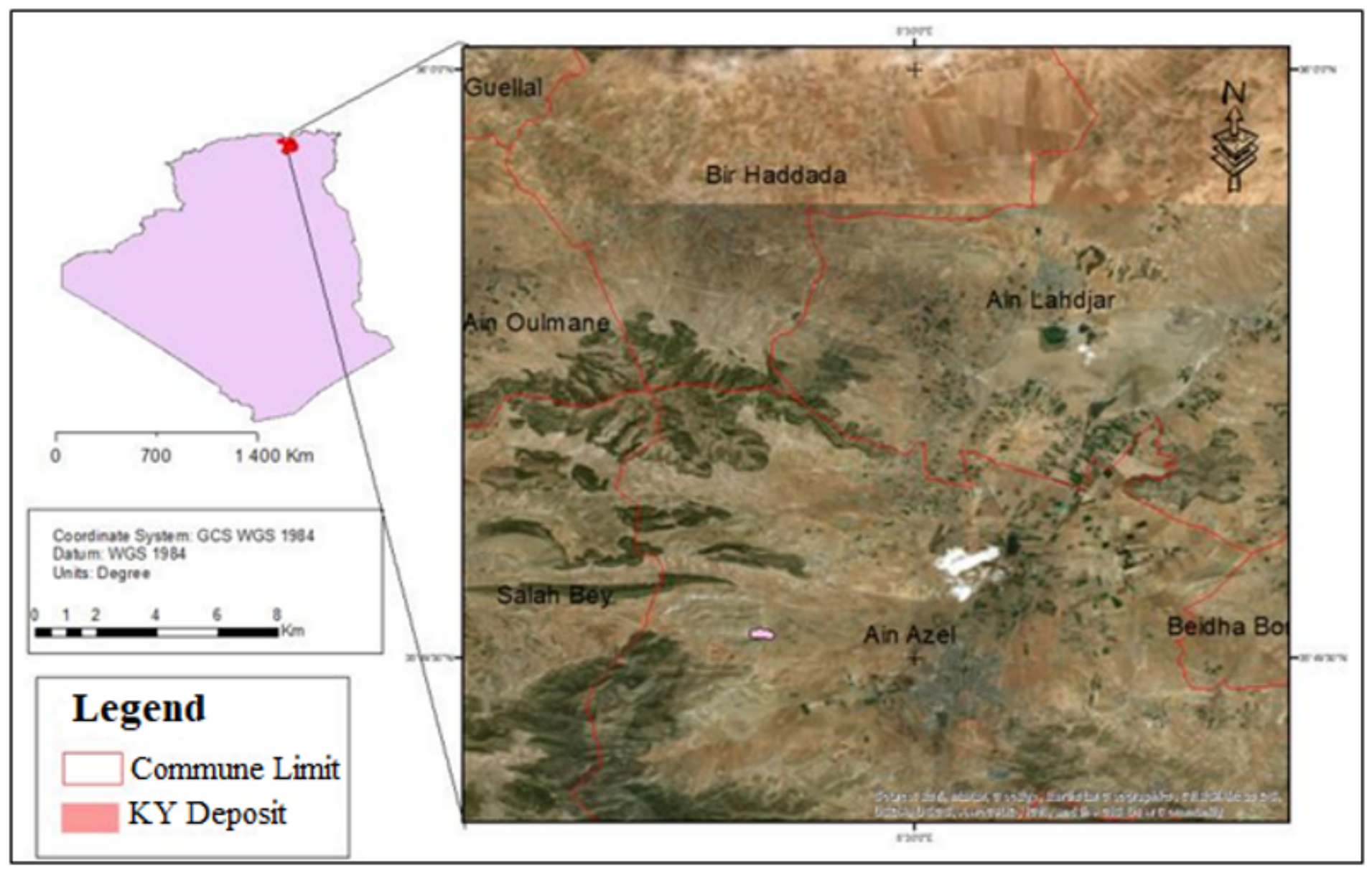

Figure 1

Geographical location map 


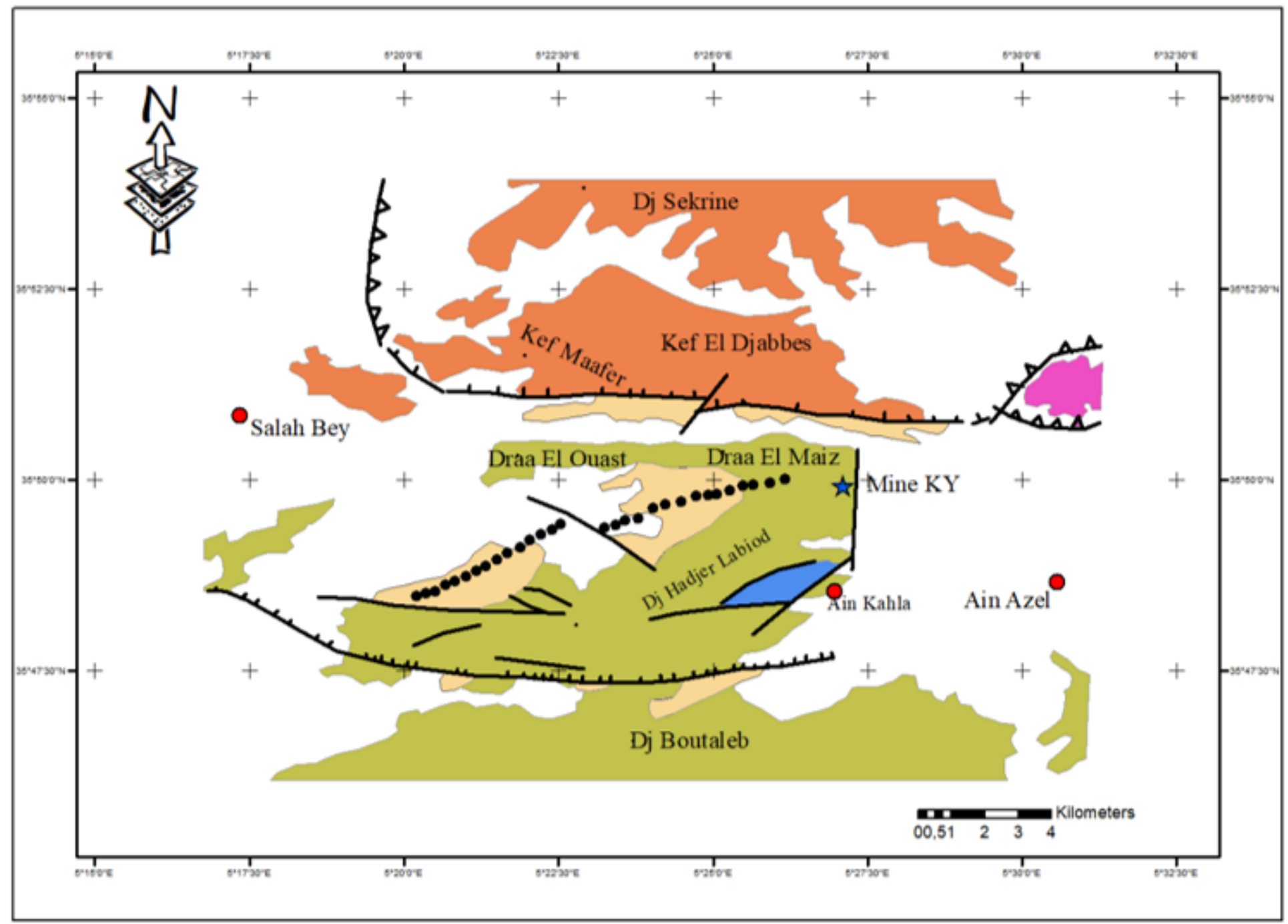

\section{Légende}

K.Y. mine
Town
\begin{tabular}{|l}
\hline Quatemary \\
Miocene
\end{tabular}
Cretaceous
Jurassic
Trias
South Seiifien

Coordinate System: WGS 1984 Web Mercator A uxiliary Sphere Projection: Mercator Auxiliary Sphere

Datum: WGS 1984

False Easting: 0,0000

False Northing: 0,0000

Central Meridian: 0,0000

Standard Parallel 1: 0,0000

Auxiliary Sphere Type: 0,0000

Units: Meter

Figure 2

Simplified structural map (Extract from geological map, Sheet 143 Ain Azel at 1/50,000) 


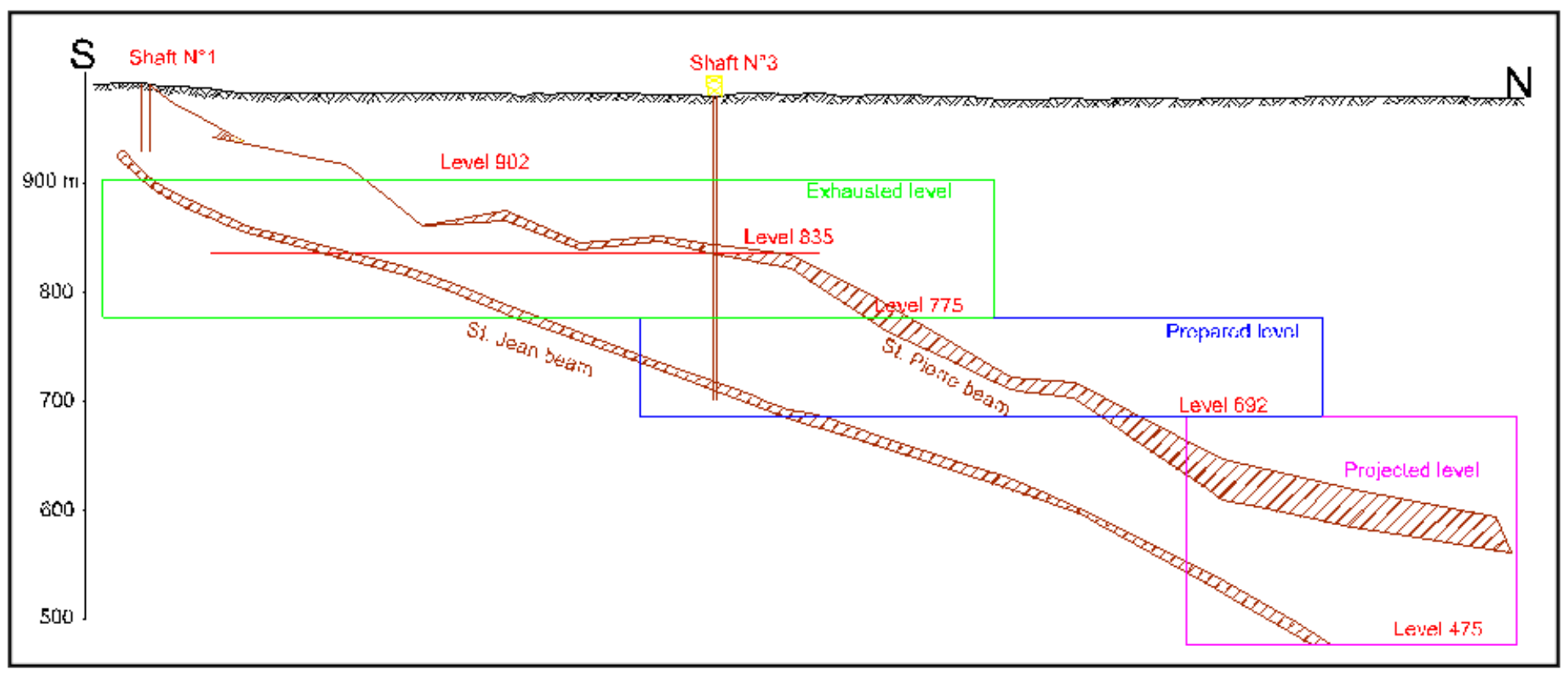

\section{Figure 3}

Longitudinal section of the Kherzet Youcef deposit

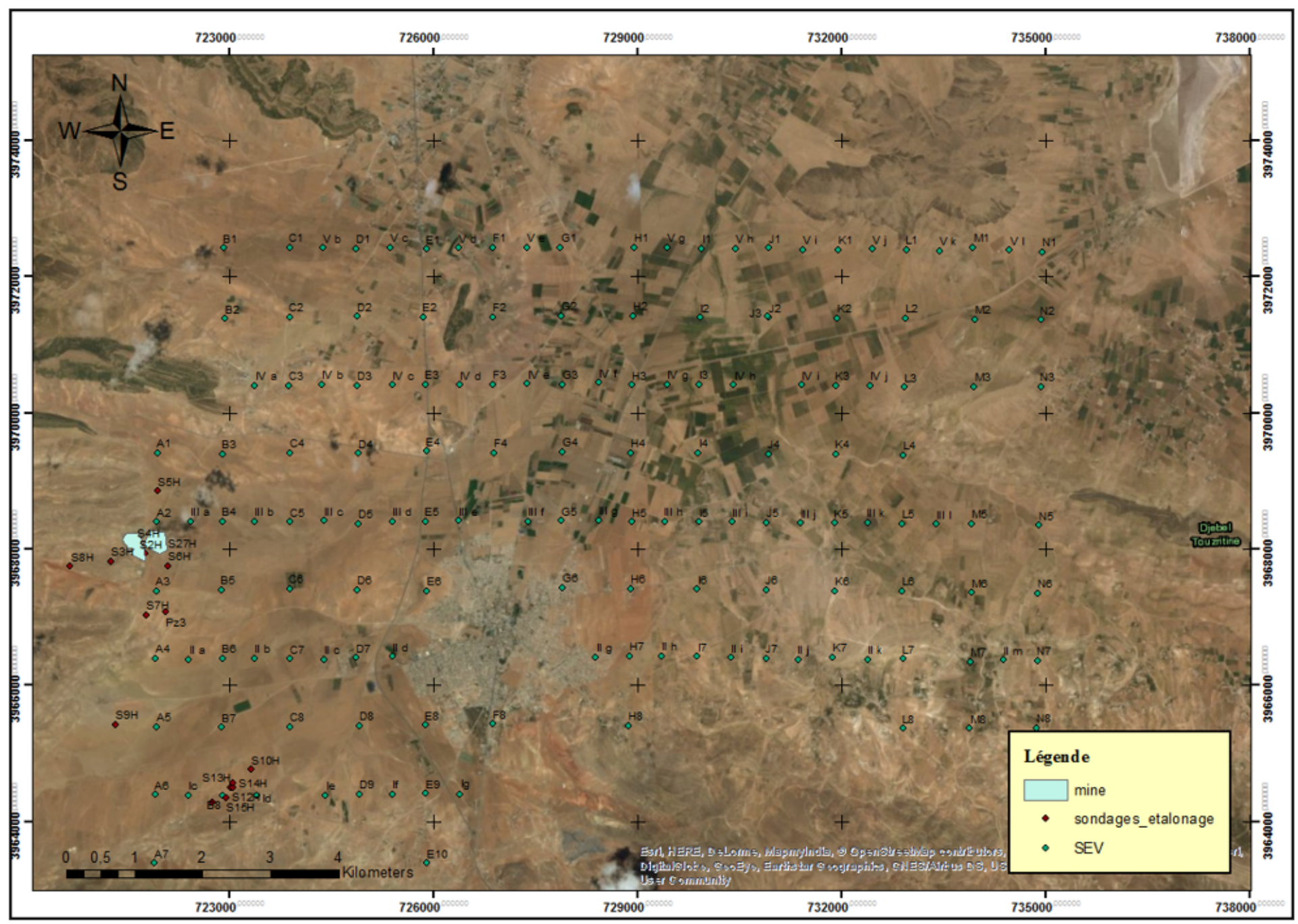




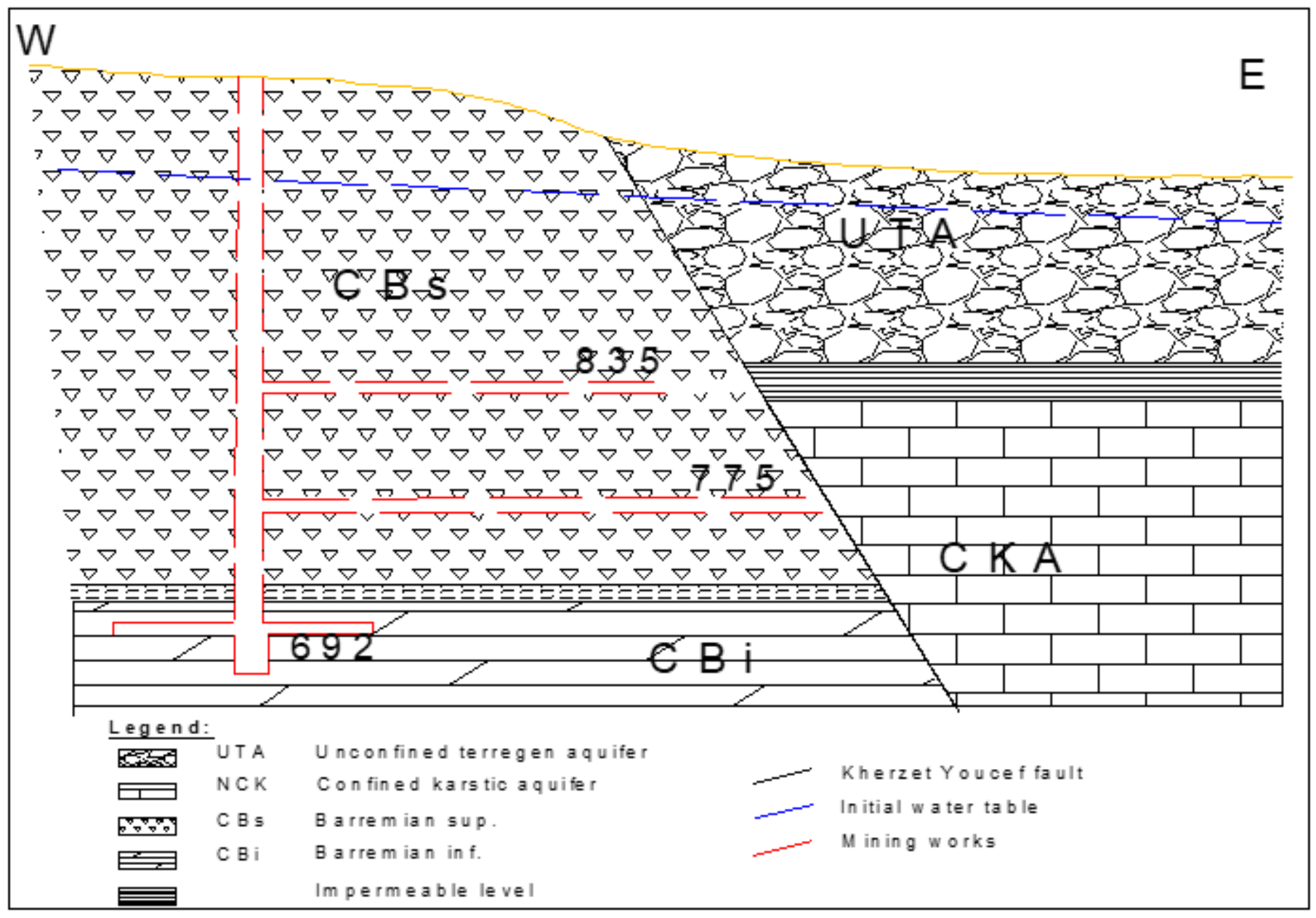

\section{Figure 5}

Longitudinal section of Kherzet Youcef deposit

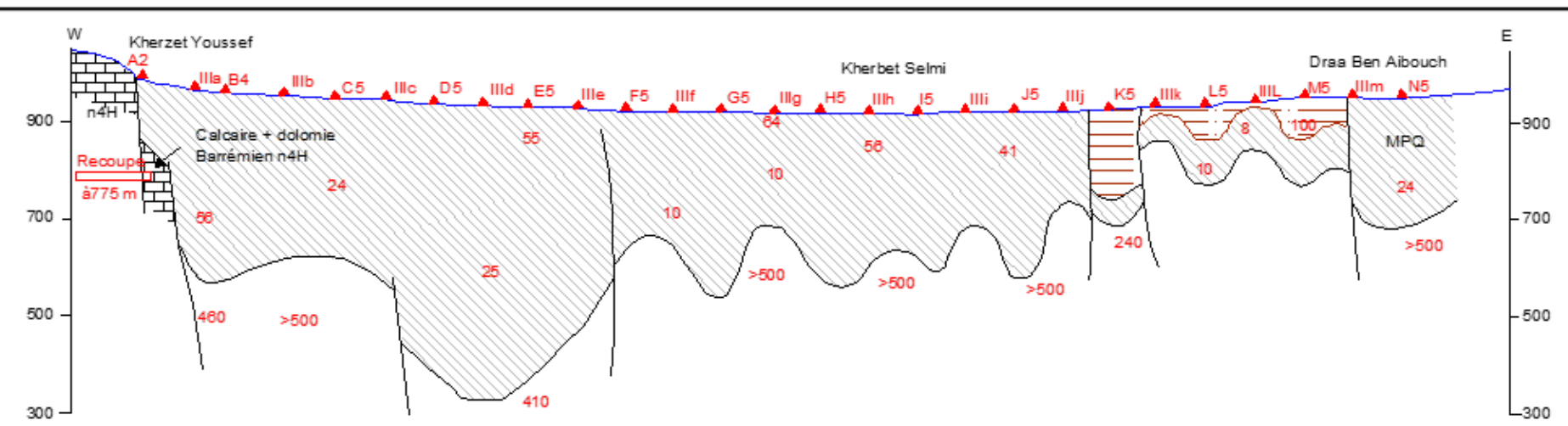

Figure 6

Longitudinal geo-electrical section 


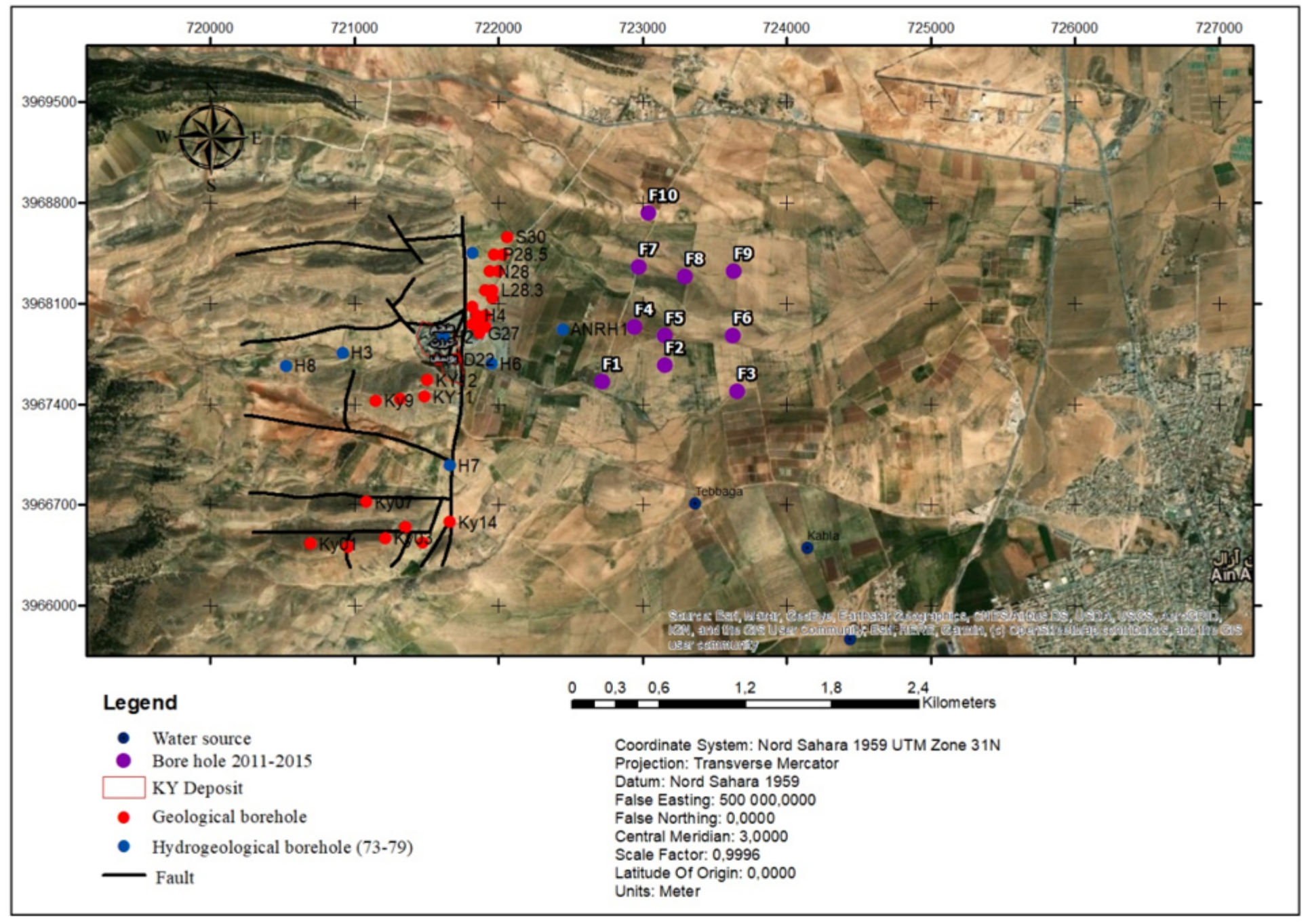

Figure 7

Implantation of observation piezometers 


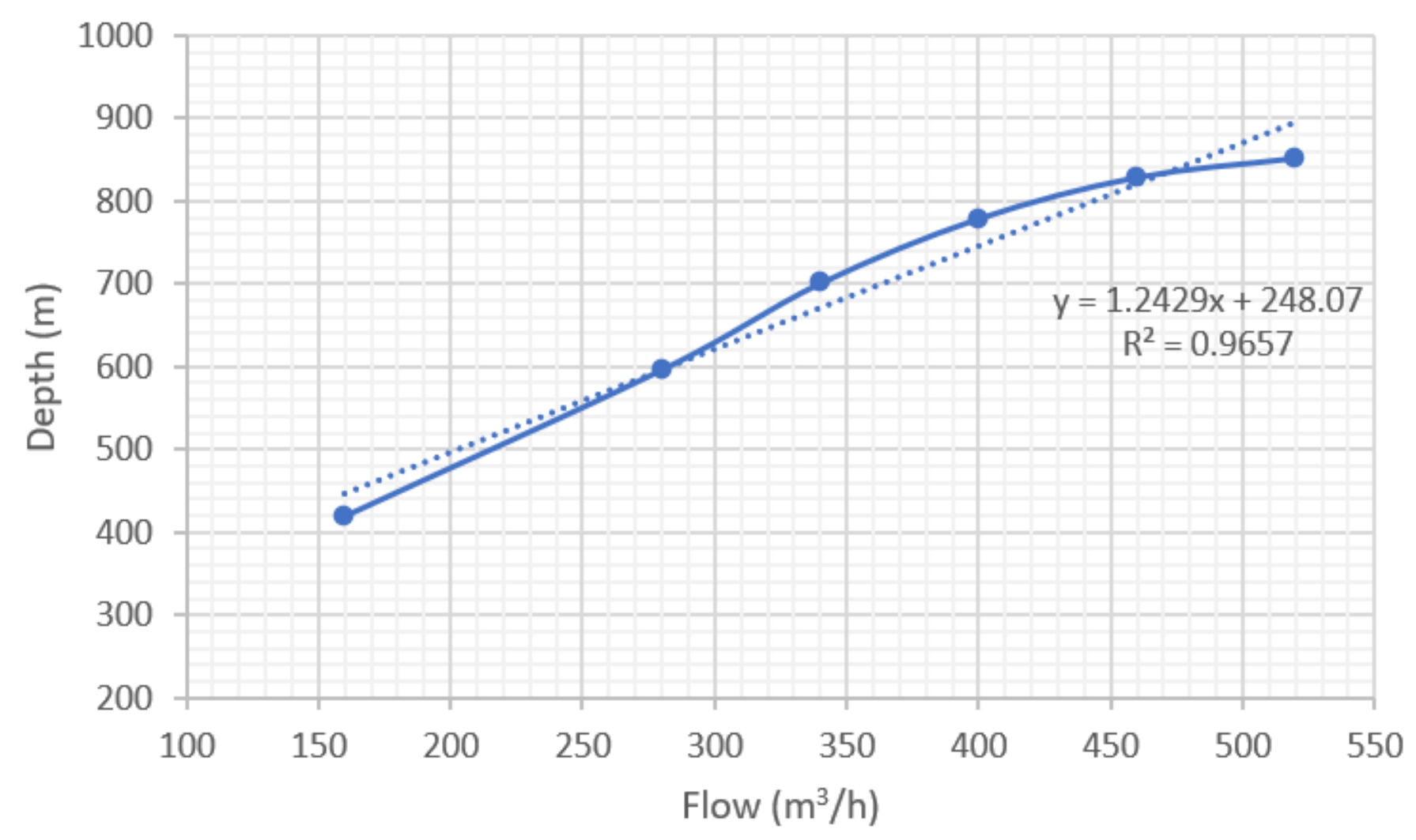

Figure 8

Correlation between the depth and the flow of the calculated water flows

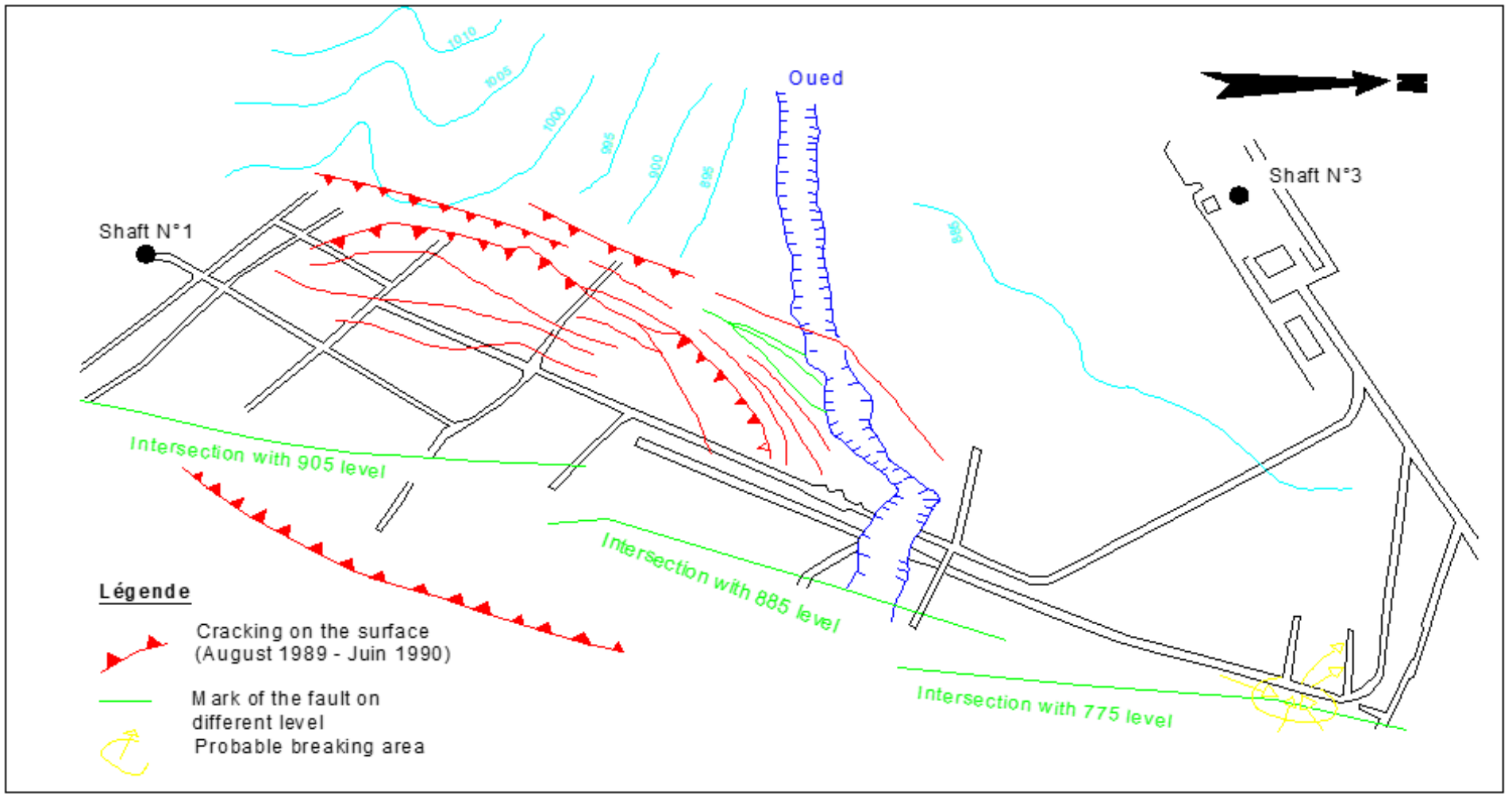


Figure 9

Cracking, fault, main mining works and probable rupture zone of the Kherzet Youcef deposit

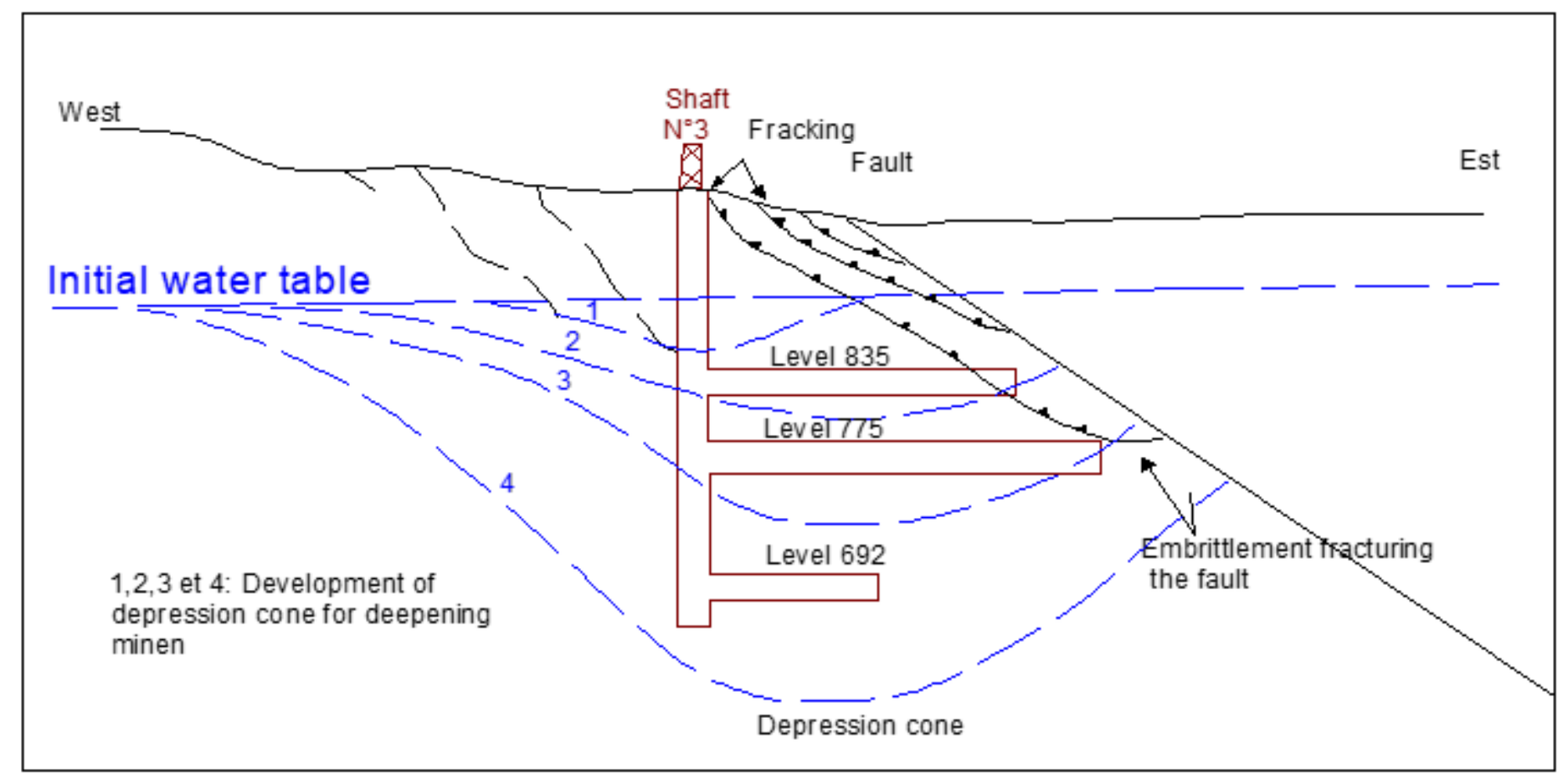

Figure 10

Hydrogeological imbalance by mining the Kherzet Youcef deposit

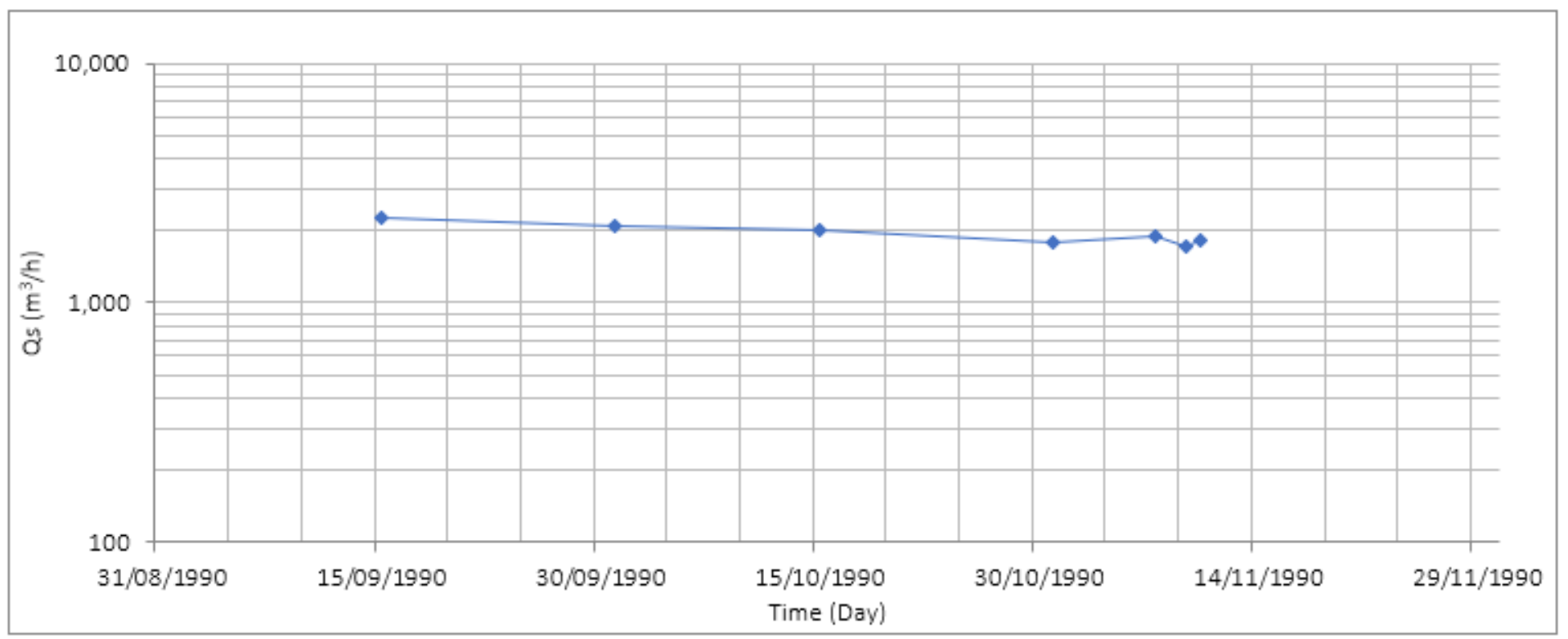

\section{Figure 11}

Variation of water flow as a function of time 